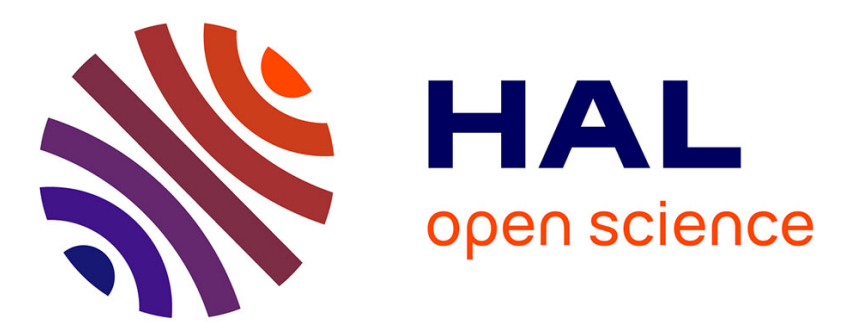

\title{
Comparison of neutral and adaptive differentiation in the Mediterranean grass Brachypodium retusum
}

Christel Vidaller, Alex Baumel, Marianick Juin, Thierry Dutoit, Armin Bischoff

\section{- To cite this version:}

Christel Vidaller, Alex Baumel, Marianick Juin, Thierry Dutoit, Armin Bischoff. Comparison of neutral and adaptive differentiation in the Mediterranean grass Brachypodium retusum. Botanical Journal of the Linnean Society, 2020, 192 (3), pp.536-549. 10.1093/botlinnean/boz089 . hal-02983389

\section{HAL Id: hal-02983389 \\ https://hal-amu.archives-ouvertes.fr/hal-02983389}

Submitted on 29 Oct 2020

HAL is a multi-disciplinary open access archive for the deposit and dissemination of scientific research documents, whether they are published or not. The documents may come from teaching and research institutions in France or abroad, or from public or private research centers.
L'archive ouverte pluridisciplinaire $\mathbf{H A L}$, est destinée au dépôt et à la diffusion de documents scientifiques de niveau recherche, publiés ou non, émanant des établissements d'enseignement et de recherche français ou étrangers, des laboratoires publics ou privés. 


\title{
Comparison of neutral and adaptive differentiation in the Mediterranean grass Brachypodium retusum
}

\author{
CHRISTEL VIDALLER ${ }^{1, *, \oplus, ~ A L E X ~ B A U M E L ~}{ }^{2}$, MARIANICK JUIN $^{3}$, THIERRY DUTOIT $^{1}$ and \\ ARMIN BISCHOFF ${ }^{1}$
}

\author{
${ }^{1}$ Institut Méditerranéen de Biodiversité et d'Ecologie marine et continentale (IMBE), Univ Avignon, Aix \\ Marseille Univ, CNRS, IRD, IUT site Agroparc, 337 Chemin des Meinajaries BP 61207, F-84911 Avignon \\ cedex 09, France \\ ${ }^{2}$ Institut Méditerranéen de Biodiversité et d'Ecologie marine et continentale (IMBE), Univ Avignon, Aix \\ Marseille Univ, CNRS, IRD, station marine d'Endoume, chemin de la batterie des lions, 13007, Marseille, \\ France \\ ${ }^{3}$ Institut Méditerranéen de Biodiversité et d'Ecologie marine et continentale (IMBE), Univ Avignon, Aix \\ Marseille Univ, CNRS, IRD, Technopole de l'environnement Arbois-Méditerranée, BP80, F-3545 Aix-en- \\ Provence Cedex 04, France
}

Received 1 February 2019; revised 3 September 2019; accepted for publication 23 October 2019

The Mediterranean grass Brachypodium retusum is the dominant species of a vulnerable steppe habitat. Differentiation in phenotypic traits has been found in a previous study, but scales and drivers are largely unknown. In this study, we compared molecular and phenotypic variation between populations to (1) analyse spatial patterns of neutral genetic variation; (2) test for effects of selection on differentiation and (3) identify major drivers of adaptive differentiation. We collected plant material of 17 populations in the western Mediterranean covering a large part of the species range. Neutral population differentiation was estimated using AFLP markers. A regional-scale subset of pairs of French populations was sampled in close proximity from calcareous and red Mediterranean soils as major habitat types. Sampling sites differed in climate at a regional scale and in soil characteristics such as $\mathrm{pH}$ at a local scale. These populations were grown in a common garden experiment to measure phenotypic traits. To test for the effects of selection on phenotypic differentiation, we calculated pairwise $\theta_{S T}$ values based on neutral AFLP markers and compared them to pairwise $P_{S T}$ values using phenotypic traits. Global dataset $\theta_{S T}$ indicated significant neutral genetic differentiation between western Mediterranean populations. In the French populations, $P_{S T}$ of vegetative and reproductive traits were higher than $\theta_{S T}$, suggesting that directional selection contributed to phenotypic population differentiation. We also found significant local-scale differentiation between soil types, but differentiation was substantially higher at the regional scale, pointing towards climate as a stronger selective factor than soil type. Mean temperature of the hottest month and winter frost frequency were identified as major drivers of adaptive differentiation. The study demonstrated the importance of combining neutral marker and phenotypic trait analysis at different spatial scales to evaluate genetic structure. Despite relatively low differentiation in AFLP markers, environmental pressure was sufficient to maintain phenotypic differentiation at regional scales.

ADDITIONAL KEYWORDS: $\theta_{S T}-$ common garden - dry grassland - neutral markers $-P_{S T}-$ phenotypic traits.

\section{INTRODUCTION}

Selection, genetic drift and gene flow shape diversity, structure and genetic variation of plant populations (Lenormand, 2002; Leimu \& Fischer, 2008). Adaptive differentiation is widespread in grassland species,

*Corresponding author. E-mail: christel.vidaller@gmail.com and plants often show adaptation at regional scales (Becker et al., 2008; Bucharova et al., 2016). In grassland populations, climate is the major largescale environmental factor driving genetic divergence, in particular temperature, precipitation and their seasonal distribution (Manel et al., 2012; Bucharova et al., 2016; Segarra-Moragues et al., 2016). Soil conditions often vary at local scales resulting in 
small-scale adaptive differentiation (Van der Putten et al., 2004; Macel et al., 2007). Soil chemistry, structure and organisms are potential selective forces (Wardle, 2002; Segarra-Moragues et al., 2016). Several studies have shown adaptation of grass species to soil type including serpentine soils (e.g. Freitas \& Mooney, 1996 for Bromus hordeaceus L. and Meimberg et al., 2010 for Aegilops triuncialis L.) or fertility gradients (Sherrard \& Maherali, 2012). For example, $\mathrm{pH}$ is one key soil chemistry factor to which plant populations may be adapted (Macel et al., 2007; Raabová et al., 2011). Soil characteristics and climate also influence land management, which is a third important driver of adaptive differentiation in grassland systems. In particular, grazing intensity depending on soil quality is known to affect plant performance and may select for genotypes that tolerate above-ground plant damage (Bullock et al., 2001; Hufford \& Mazer, 2012).

Nevertheless, genetic differentiation is not only the result of adaptation to different environments. Stochastic processes such as genetic drift considerably contribute to population differentiation and may limit local adaptation (Hereford \& Winn, 2008; Hereford, 2009). Genetic drift and limited dispersal often result in isolation-by-distance effects not related to environmental gradients (Sexton et al., 2014).

Our study species, Brachypodium retusum (Pers.) P.Beauv., is a common perennial grass that grows in dry grasslands, shrublands and open woodlands of the western Mediterranean Basin. It is the characteristic and dominant species of the Natura 2000 habitat 'pseudo-steppe with grasses and annuals' protected by the EU habitats directive (San Miguel, 2008). This dry grassland community is still widespread in the western Mediterranean but is threatened by overgrazing, conversion to arable land or, in contrast, by land abandonment (San Miguel, 2008). Restoration approaches using $B$. retusum seed have often failed due to poor recruitment (Coiffait-Gombault et al., 2012), and there is an urgent need for a better understanding of relations between genetic differentiation and local environment to improve restoration success by better targeting source populations (Breed et al., 2018). The genetic structure of the introduced populations influences plant establishment and introducing nonlocal populations may thus compromise the success of plant introductions (Hufford \& Mazer, 2003; Vander Mijnsbrugge et al., 2010).

In the French part of the $B$. retusum range, two major environmental gradients have been identified. First, the species occurs on calcareous soils of lower mountain ranges and on decarbonated red Mediterranean soils of former river valleys but is absent from lowlands with deep clay and loam soils (Vidaller et al., 2018). Second, the major climatic factor varying in the study region is rainfall increasing from the east to the west. In a previous common garden study on a subset of populations, significant differentiation was found between soil types within sites with the same climate, although differentiation between sites of different climate was much stronger (Vidaller et al., 2018).

Classical common garden experiments testing for phenotypic differentiation do not allow drift and adaptation as driving forces to be distinguished (Vidaller et al., 2018). Molecular markers provide a powerful tool to study neutral genetic variation and to compare it with potentially adaptive phenotypic traits (Brommer, 2011; Leinonen et al., 2013; Durka et al., 2017). Meta-analyses have shown that differentiation in phenotypic traits is often higher than differentiation in neutral markers, since gene flow reduces neutral variation but differentiation in traits that are under strong selection is maintained (Leinonen et al., 2008; Kort et al., 2013). Thus, comparisons of phenotypic traits and neutral markers provide valuable insights into the causes of spatial genetic divergence among populations (Leinonen et al., 2008). In particular, they may help in disentangling the contribution of climate and genetic drift to population differentiation often occurring at similar spatial scales (Durka et al., 2017).

Using AFLP markers, we aimed to analyse the spatial genetic structure at a western Mediterranean and at a regional southern French scale. Using the southern French subset of populations, we tested whether neutral genetic variation corresponds to variation in phenotypic traits measured in a common garden. We correlated differentiation at regional level with climate and soil factors to identify the major environmental drivers of adaptive differentiation.

More specifically, we address the following research questions. (1) What is the structure of genetic diversity of $B$. retusum at a western Mediterranean scale? (2) Does the comparison of phenotypic differentiation and neutral genetic differentiation provide evidence for environmental selection pressure at a regional scale in southern France? (3) What are the major drivers of adaptive differentiation; in particular, what is the role of local-scale soil type compared with large-scale climate?

\section{MATERIAL AND METHODS}

\section{STUDY SPECIES AND SAMPLING}

Brachypodium retusum (ramose false brome; Poaceae) is a rhizomatous perennial $\mathrm{C}_{3}$ grass species. It is a predominantly outcrossing wind-pollinated species that shows high levels of clonal growth, but also sexual reproduction. Its rhizomes form a dense network close to the soil surface resulting in a high resilience to 
above-ground disturbance such as wildfires or grazing (Caturla et al., 2000). Brachypodium retusum is an allopolyploid with $2 n=36$ or 38 chromosomes and is probably a tetraploid (Wolny \& Hasterok, 2009; Wolny et al., 2011; Catalán et al., 2012). Its progenitors are unknown and probably extinct, but one of its genomes may be related to the lineage of $B$. distachyon (L.) P.Beauv. and the other to the lineage of the core perennial species of Brachypodium P.Beauv. (Catalán et al., 2012).

Plant material of 17 populations was collected in the western Mediterranean Basin from northern Italy to southern Spain focusing on southern French populations (Table S1). For 15 populations, we collected plant material (seeds or leaves) from 20 patches with a minimum distance of $10 \mathrm{~m}$ between patches to avoid collecting clones. In each patch, we used only one seed or leaf for further analyses resulting in 20 different mother plants per population. Two populations were bulk samples with unknown numbers of mother plants (SES, ROQ, Table S1). Southern French populations were collected in pairs from base-rich calcareous soils of lower mountain ranges and from decalcified red Mediterranean soils (haplic cambisols) in close proximity. Calcareous soils are shallow on calcareous bedrock with an average soil $\mathrm{pH}$ of 8.4. Red Mediterranean soils have a higher clay content resulting in a better nutrient and water retention ( $\mathrm{pH}$ 7.3). Because of the higher soil fertility and accessibility, grasslands on red Mediterranean soils were more intensively used in the past (in particular grazing) than those on calcareous soils. In 16 populations, seeds were sampled at natural sites and later on grown in a common garden (see below) or in a growth chamber. Leaves for AFLP analysis were then sampled from these seed-grown plants. In one population, leaves were directly sampled in the field. Vouchers of plant material from each population were deposited in the Herbarium of Aix Marseille University (MARS, Marseille, France) (Table S1). Climate data for the French collection sites were obtained from the closest meteorological station (distance $<15 \mathrm{~km}$ ), and $\mathrm{pH}$ values were measured on soil sampled in the field.

\section{SAMPLE PREPARATION AND DNA EXTRACTION}

Leaves of 20 plants per population (ten for ROQ population) were collected for AFLP analysis, resulting in a total of 366 plants. Between 10-15 mg of silica-dried and further frozen leaves from the field, greenhouse-cultivated samples were ground in a TissueLyser mixer mill (Quiagen-Retsch). Total DNA was extracted using NucleoSpin Plant II Kit (Macherey \& Nagel, Germany) (Supplementary data, detailed method description 1). DNA concentrations were measured using a photometer (Biophotometer, Eppendorf, Germany)

\section{AFLP GENOTYPING}

AFLP markers are able to reveal the structure of genetic diversity based on hundreds of loci for polyploids (e.g. Balao et al., 2010; Hardion et al., 2014) and offer the possibility of comparing phenotypic and genomic differentiation, while controlling for outlier loci potentially under selection.

Following Vos et al. (1995), $100 \mathrm{ng}$ of DNA was digested using the restriction enzymes EcoR1 and Tru 91 (Fisher Scientific, France) in a total volume of $25 \mu \mathrm{l}$ $\left(15 \mu \mathrm{L}+10 \mu \mathrm{L}\right.$ DNA), with a first step for $3 \mathrm{~h}$ at $37^{\circ} \mathrm{C}$ and a second step for $3 \mathrm{~h}$ at $65^{\circ} \mathrm{C}$. Digestion products were immediately ligated to $0.5 \mu \mathrm{L}$ EcoR 1 and $25 \mu \mathrm{L}$ Mse adaptors for $3 \mathrm{~h}$ at $37^{\circ} \mathrm{C}$ and treated with T4 DNA ligase and $0.1 \mu \mathrm{L}$ of $100 \mathrm{mM}$ ATP to a final volume of $25 \mu \mathrm{L}(5 \mu \mathrm{L}+20 \mu \mathrm{L}$ restriction products). Ligation products were diluted eight times, and pre-selective PCR amplification was performed using EcoR1+A, Mse $+\mathrm{C}$ primers and Taq DNA polymerase in $44.5 \mu \mathrm{L}$. The pre-amplification thermocycle profile was $94^{\circ} \mathrm{C}$ for $2 \mathrm{~min}$, followed by 20 cycles at $94{ }^{\circ} \mathrm{C}$ for $45 \mathrm{~s}, 56^{\circ} \mathrm{C}$ for $45 \mathrm{~s}, 72{ }^{\circ} \mathrm{C}$ for $1 \mathrm{~min}$ and $72{ }^{\circ} \mathrm{C}$ for $10 \mathrm{~min}$. Four primer combinations were chosen for the selective amplification PCR: ASI: EcoR1-AAC/Mse1-CAA, ASII: EcoR1-AGG/ Ms1-CGG, ASIII: EcoR1-AGC/ Mse1CAG, ASIV: EcoR1-ATG/ Mse1-CTA labelled with 6-FAM fluorescence at the $5^{\prime}$ EcoR1 end (Eurofins Genomics, Ebersberg, Germany). pre-amplification products diluted 100 -fold were used to perform selective amplification in a final volume of $20 \mu \mathrm{L}$ ( $15 \mu \mathrm{L}+5 \mu \mathrm{L}$ diluted pre-amplification products). For the selective amplification thermocycle profile, we used $94{ }^{\circ} \mathrm{C}$ for $2 \mathrm{~min}$, ten cycles of $94{ }^{\circ} \mathrm{C}$ for $30 \mathrm{~s}, 65^{\circ} \mathrm{C}$ for $30 \mathrm{~s}$ (step $-1^{\circ} \mathrm{C}$ per cycle), $72^{\circ} \mathrm{C}$ for $1 \mathrm{~min}$, followed by 22 cycles at $94{ }^{\circ} \mathrm{C}$ for $30 \mathrm{~s}, 56^{\circ} \mathrm{C}$ for $30 \mathrm{~s}, 7{ }^{\circ} \mathrm{C}$ for $1 \mathrm{~min}, 72{ }^{\circ} \mathrm{C}$ for $5 \mathrm{~min}$ and $4{ }^{\circ} \mathrm{C}$ for $2 \mathrm{~h}$. The fragment length produced by the amplification was separated and quantified by capillary electrophoresis using an ABI 3730xl DNA Analyzer (Applied Biosystems, Foster City, CA, USA) using GS600 LIZ as the size marker.

\section{ANALYSIS OF PHENOTYPIC TRAITS IN COMMON GARDEN PLANTS}

To understand genetic differentiation based on phenotypic traits, individuals from 13 French populations were grown for two years in a common garden. In December 2015, collected seeds were germinated in peat plugs $(4 \times 4 \mathrm{~cm})$, placed in a growth chamber (temperature $15 / 20^{\circ} \mathrm{C}, 12 / 12 \mathrm{~h}$, night/ day) and watered regularly. In March 2016, 24 plugs per population (corresponding to 24 patches) were 
randomly selected and transplanted to a previously ploughed experimental site in Avignon-Montfavet. Two plugs per population were planted to random positions in each of 12 blocks $\left(3 \times 3 \mathrm{~m}^{2}\right)$. During the first four months, seedlings were moderately watered. Plots were hand-weeded to limit competition. Plant height, diameter, tiller number, leaf number and the length of the longest leaf were measured for two growing seasons. In the present study, we used the measurements of the second growing season.

\section{DATA ANALYSIS}

\section{Large-scale genetic structure using AFLP}

Peaks were scored in Peak Scanner v.1.0 (Applied Biosystems) as present (1), absent (0) or 'no data' (NA) if they were not unambiguously identified. In Raw Geno 2.0 (Arrigo et al., 2009), only fragments between 100 and 500 bp were considered. Maximum binning between peaks was set at 1.75 and minimum at 1.5. The reliability of AFLP markers was checked by repeating the complete analysis from DNA amplification to AFLP screening on 16 samples for each pair of primers. A Bayesian analysis using BAYESCAN (Foll \& Gaggiotti, 2008) was run to detect loci potentially under selection (outliers) and remove them for further analysis to focus on neutral genetic diversity. The analysis was performed using ten pilot runs of length 1000, a burn-in of 50000 followed by 60000 iterations, 1000 sample sizes and ten thinning intervals. BAYESCAN is the most widespread differentiation-based method to detect loci under selection (Vilas et al., 2012) and is frequently used with AFLP data (e.g. Bertin et al., 2017). Two datasets were used, a global one to understand large-scale genetic structure and a subsample to analyse genetic structure at regional scale using AFLP and quantitative traits.

Diversity indices were estimated using $R$ package poppr. Parameters of genetic diversity (percentage of polymorphic loci, number of multilocus genotypes, Shannon-Wiener Index of MLG diversity, Nei's diversity index of expected heterozygosity and standardized index of association) were calculated for each population. Genetic differentiation among populations was analysed using divergence at neutral marker $\theta_{S T}$, an analogue of $F_{S T}$ for binary data using GenAlEx 6.5 (Peakall \& Smouse, 2012). The significance test of $\theta_{S T}$ was based on 9999 permutations. A UPGMA tree was constructed from the matrix of pairwise population differences ( $R$ package phangorn).

\section{Regional-scale genetic structure: phenotypic and neutral marker differentiation}

For a subset of 13 southern French populations, the mean $\theta_{S T}$ was compared to the mean $P_{S T}$ based on phenotypic traits. Comparisons between phenotypic
$\left(P_{S T}\right)$ and genomic $\left(\theta_{S T}\right)$ differentiation assume that $\theta_{S T}$ provides a null expectation without selection when controlled for outliers potentially under selection (Leinonen et al., 2013). Thus, the comparison of $P_{S T}$ with $\theta_{S T}$ allows distinguishing selection from other evolutionary forces. A higher $P_{S T}$ value compared with $\theta_{S T}$ indicates directional natural selection favouring different phenotypes in different populations (= adaptive differentiation). A higher $\theta_{S T}$ suggests stabilizing selection for similar phenotypic traits in different populations.

A Bayesian analysis using the software STRUCTURE 2.2 (Pritchard et al., 2007) was applied to assess genetic structure among AFLP samples. STRUCTURE uses an iterative approach to cluster genotypes into $K$ populations without a priori knowledge to which population individuals belong. From $K=1$ to $K=13$ populations, and for each $K$ solution ten replicates were run with 100000 burn-in simulations followed by two million simulations per replicate. Using STRUCTURE, direct posterior probabilities for $K$ (loglikelihood) and the ad hoc statistic $\Delta K$ (Evanno et al., 2005 ) were estimated using uniform a priori values of $K$ between one and 13 (total number of populations).

Separate PCA were run on vegetative (plant height, diameter, tiller number, leaf number and length) and reproductive phenotypic traits (inflorescence and spikelet number). We used first axis PCA scores as a synthetic response variable considering several phenotypic traits at the same time to calculate $P_{S T}$ values (divergence in quantitative traits). Calculations were run using R package Pstat with 9999 bootstraps (Da Silva \& Da Silva, 2018), but sums of squares (SS) were used as variance estimates instead of mean sums of squares to compare $P_{S T}$ to $\mathrm{SS}$ based $\theta_{S T}\left(P_{S T}\right.$ is analogous to $Q_{S T}$ and is used if heritability estimates cannot be measured; Brommer, 2011):

$$
P_{S T}=\frac{c \sigma_{B}^{2}}{c \sigma_{B}^{2}+2 h^{2} \sigma_{W}^{2}}=\frac{\frac{c}{h^{2}} \sigma_{B}^{2}}{\frac{c}{h^{2}} \sigma_{B}^{2}+2 \sigma_{W}^{2}}
$$

with $\sigma_{B}^{2}$ being the phenotypic variance between populations, $\sigma_{W}^{2}$ the phenotypic variance within populations, $c$ the proportion of the total variance explained by additive genetic effects and $h^{2}$ the heritability, proportion of phenotypic variance explained by additive genetic effects. The null assumptions were chosen for $\frac{c}{h^{2}}$ parameters with $c=h^{2}=1$ (Brommer, 2011, see Supporting Information, detailed method description 2).

To evaluate local soil type versus regional-scale differentiation (climate, drift), the two adjacent populations from red Mediterranean and calcareous soils were considered to be originating from the 
same site resulting in six sites and two soil types per site. Thus, each population represented a particular combination of site and soil. For AFLP markers, we applied an analysis of molecular variance (AMOVA) based on $\theta_{S T}$ statistics using GenAlEx 6.0. An ANOVA was calculated to analyse the effect of site, soil and the soil $\times$ site interaction on the first PCA axis.

A multiple regression on distance matrices (MRM) was used to identify variables (climate distance, geographic distance, genetic distance and $\mathrm{pH}$ distance) that best predicted $P_{S T}$ distance among populations. Additionally, partial distance-based redundancy analyses (dbRDA) was applied to evaluate the relationship between divergence in phenotypic traits and environmental variables including January, July and mean annual temperatures, number of frost days, annual precipitation and soil pH (Rpackage Vegan). Partial dbRDA were fitted separately for $P_{S T}$ of vegetative and reproductive traits using permutation testing (Legendre \& Anderson, 1999). First, a marginal test was performed using only environmental variables as predictors. Second, a conditional test was run using genetic distance and geographical coordinates as covariates to take into account the potential confounding effects of isolation by neutral genetic drift. The genetic distance matrix was transformed into continuous rectangular vectors via principal coordinates analysis. The significance of environmental factors was evaluated using a dbRDA permutation test (9999 permutations). All statistical analyses were run in $\mathrm{R}$ ( R, v.3.3.1, R Development Core Team (2013)) except for genetic structure.

\section{RESULTS}

AFLP analysis allowed genotyping of 366 individuals on 587 loci. After filtering for reliable non-redundant loci (error rate < $4.39 \%$ ), suppressing unscored individuals and non-polymorphic loci, we created two datasets. A global dataset (98.48\% of polymorphic loci) with 322 individuals was genotyped on 323 loci and a southern French dataset (97.27\% of polymorphic loci) with 258 individuals was genotyped on 320 loci. Only two outliers under selection were found by BAYESCAN analysis and removed from the datasets. No clone was found in any of the datasets.

\section{LARGE-SCALE GENETIC STRUCTURE USING AFLP (GLOBAL DATASET)}

Average Shannon diversity $(H)$ of the tested populations ranged from 2.302 to 3.044 , and expected heterozygosity, $H_{e}$, ranged from 0.134 to 0.205 (Table 1). In 12 populations, the standardized index of association was significantly different from zero, rejecting the null hypothesis of no linkage between markers of 12 populations. In five populations, no linkage between markers was detected. The significant rbarD values, ranging from 0.001 to 0.101 , suggest asexual reproduction, but at rates that are different between these 12 populations. In the global data set, the Italian NIT was the only population with private alleles.

In the global dataset, the average $\theta_{S T}(0.102$; $P<0.001)$ revealed moderate genetic differentiation among the 17 populations. Pairwise $\theta_{S T}$ between populations ranged from 0.006 to 0.224 , and values were significantly different from zero except for one population pair (Table S2). The UPGMA tree calculated on the pairwise $\theta_{S T}$ matrix revealed differentiation of non-French populations, but no clear geographical pattern for French populations (Fig. 1) except for MO_R, which is genetically closer to Spanish populations.

\section{REGIONAL-SCALE GENETIC STRUCTURE: PHENOTYPIC AND NEUTRAL MARKER DIFFERENTIATION}

In the southern French dataset, the average $\theta_{S T}(0.072$; $P<0.001$ ) was lower than in the global data set and pairwise $\theta_{S T}$ between populations ranged from 0.006 to 0.197 (Table S2). The STRUCTURE analysis provided the strongest support when samples were clustered into two groups $(K=2)$ and five groups $(K=5)$ based on the $\Delta K$ method of Evanno (Fig. S1). At $K=5$, both assignment ratio by individual and geographical distribution of genetic cluster are indicating a high level of admixture (Figs 2 and 3).

Compared to differentiation in neutral AFLP markers, the phenotypic differentiation was higher. The average $P_{S T}$ for vegetative $(0.171 ; P<0.001)$ and reproductive traits $(0.138 ; P<0.001)$ revealed significant phenotypic differentiation among the 13 populations. Pairwise $P_{S T}$ between populations were 0.062 to 0.432 for vegetative and 0.066 to 0.355 for reproductive traits, respectively (Table S3). Average population differentiation was at least two times greater for phenotypic traits than for neutral markers. Confidence intervals do not overlap. Moreover, critical $\frac{c}{h^{2}}$ values for vegetative and reproductive traits are low: 0.3 and 0.4 (Fig. 4A, B).

Site of origin contributed more to the differentiation than soil of origin. The site of origin accounted for $2.33 \%$ of total variation for AFLP markers, $12.85 \%$ for vegetative traits and $8.37 \%$ for reproductive traits, whereas the soil of origin accounted for $0.62,1.92$ and $0.05 \%$, respectively (Table 2 ). Variation between soil types was still significant for AFLP markers (highly significant) and vegetative traits, but not for 
Table 1. Genetic diversity estimates in total dataset populations based on AFLP data. Populations are ranked according to longitude from east (top of the table) to west. Pop, Population name; $N$, Sample size; H, Shannon-Wiener index of MLG diversity (Shannon, 2001); He, Nei's diversity index of expected heterozygosity; rbarD, standardized index of association; p.rbarD, $P$ value of rbarD.

\begin{tabular}{|c|c|c|c|c|c|c|}
\hline Country & Pop & $N$ & $\mathrm{H}$ & $H_{e}$ & rbarD & p.rbarD \\
\hline Italy & NIT & 19 & 2.944 & 0.205 & 0.101 & 0.001 \\
\hline France & ME_C & 20 & 3.044 & 0.166 & 0.001 & 0.038 \\
\hline France & ME_R & 19 & 2.944 & 0.172 & 0.003 & 0.003 \\
\hline France & CA_C & 20 & 2.995 & 0.164 & 0.004 & 0.001 \\
\hline France & CA_R & 20 & 3.044 & 0.165 & 0.002 & 0.021 \\
\hline France & SR_C & 18 & 2.890 & 0.159 & 0.000 & 0.180 \\
\hline France & SR_R & 20 & 2.995 & 0.166 & 0.007 & 0.001 \\
\hline France & SM_C & 20 & 2.995 & 0.158 & 0.004 & 0.001 \\
\hline France & SM1_R & 20 & 2.995 & 0.165 & 0.006 & 0.001 \\
\hline France & SM2_R & 20 & 2.995 & 0.147 & 0.008 & 0.001 \\
\hline France & NI_C & 20 & 2.995 & 0.168 & 0.002 & 0.009 \\
\hline France & NI_R & 20 & 2.995 & 0.159 & 0.000 & 0.433 \\
\hline France & MO_C & 19 & 2.944 & 0.150 & 0.000 & 0.634 \\
\hline France & MO_R & 20 & 2.995 & 0.176 & 0.002 & 0.019 \\
\hline France & ROQ & 10 & 2.302 & 0.165 & 0.003 & 0.059 \\
\hline Spain & NES & 18 & 2.890 & 0.142 & 0.001 & 0.152 \\
\hline \multirow[t]{2}{*}{ Spain } & SES & 17 & 2.833 & 0.134 & 0.007 & 0.001 \\
\hline & Average & 18.941 & 2.929 & 0.162 & 0.009 & 0.091 \\
\hline
\end{tabular}

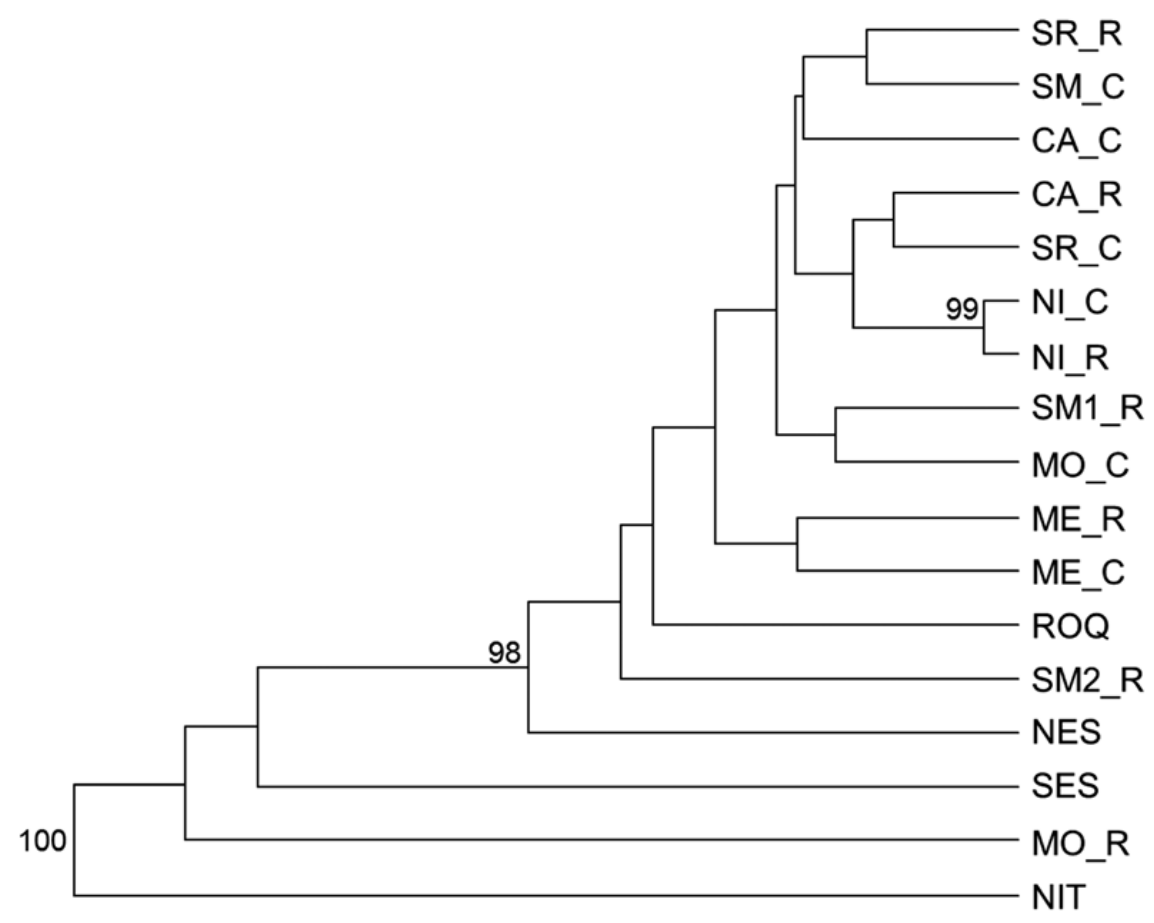

Figure 1. UPGMA dendrogram and node bootstrap values based on 10000 bootstrap replicates showing the relationship between global dataset populations based on $\theta_{S T}$. Only bootstrap values $>90 \%$ are represented.

reproductive traits. The significant soil $\times$ site interaction in molecular and phenotypic traits indicated that soil type variation depends on site of origin.
Multiple regression analysis showed that phenotypic differentiation in vegetative and reproductive traits was correlated to climatic 

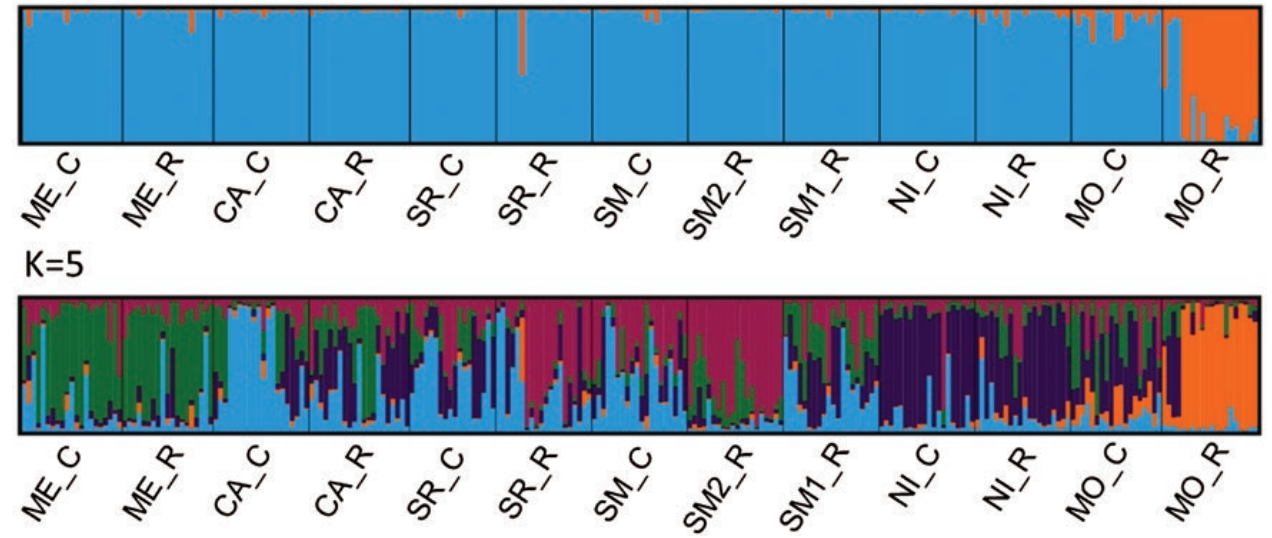

Figure 2. Genetic structure according to STRUCTURE 2.2 for $K=2$ and $K=5$ (optimum values according to Evanno method). The $y$-axis indicates the assignment ratio of each individual and individuals are assorted by population ranked from east (left) to west (right). Different colours correspond to clusters.

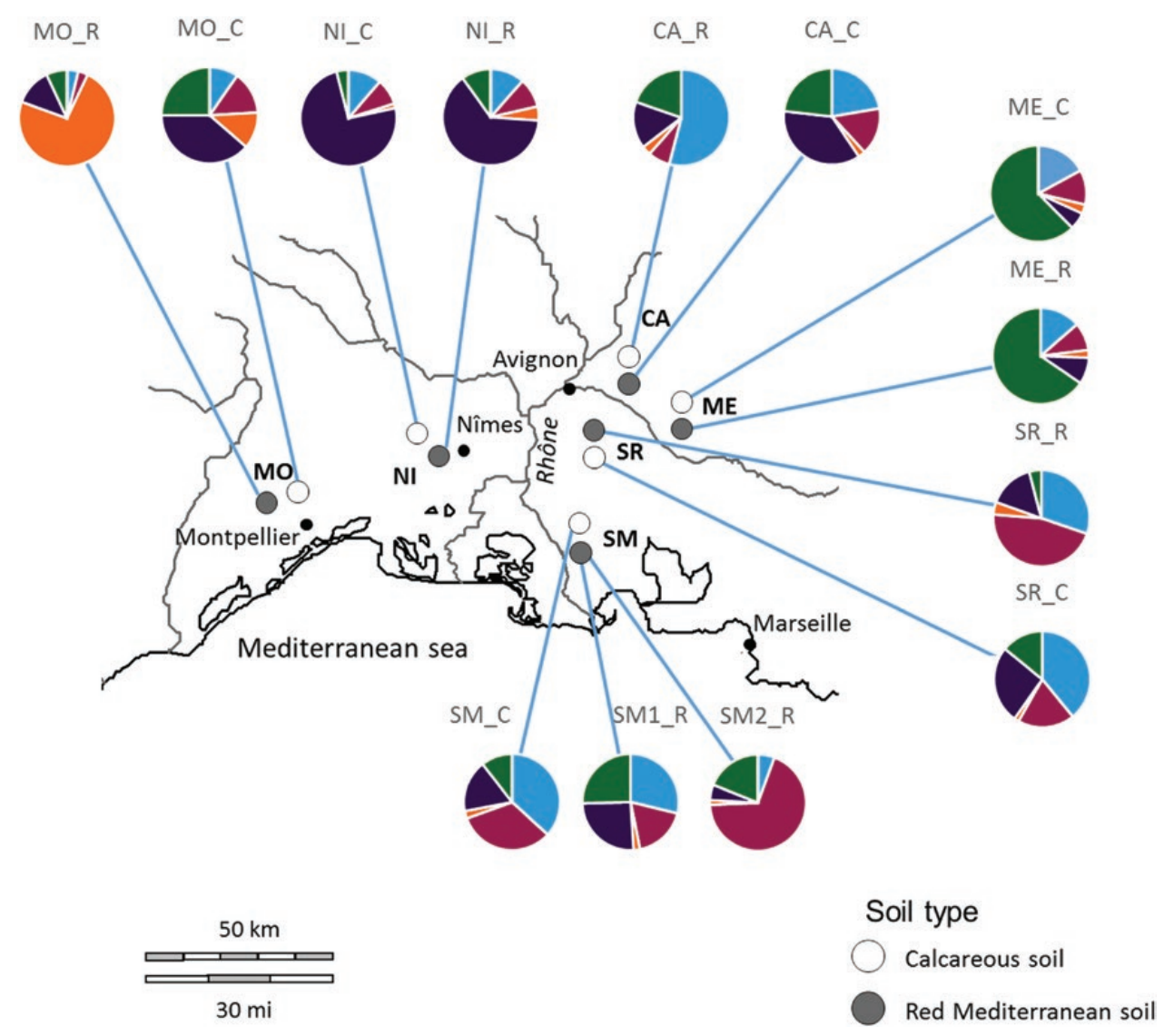

Figure 3. Geographical distribution of the genetic clusters identified by STRUCTURE 2.2 (pie charts) in southern French Brachypodium retusum populations on red Mediterranean and calcareous soil.

distance between sites but also provided evidence that differentiation in vegetative traits was partly explained by neutral genetic distances (Table 3). The dbRDA results showed a significant correlation between phenotypic trait $P_{S T}$ and climate factors when not corrected for differentiation in neutral markers confirming MRM results (Table 4A). When neutral variation in AFLP markers was 
A

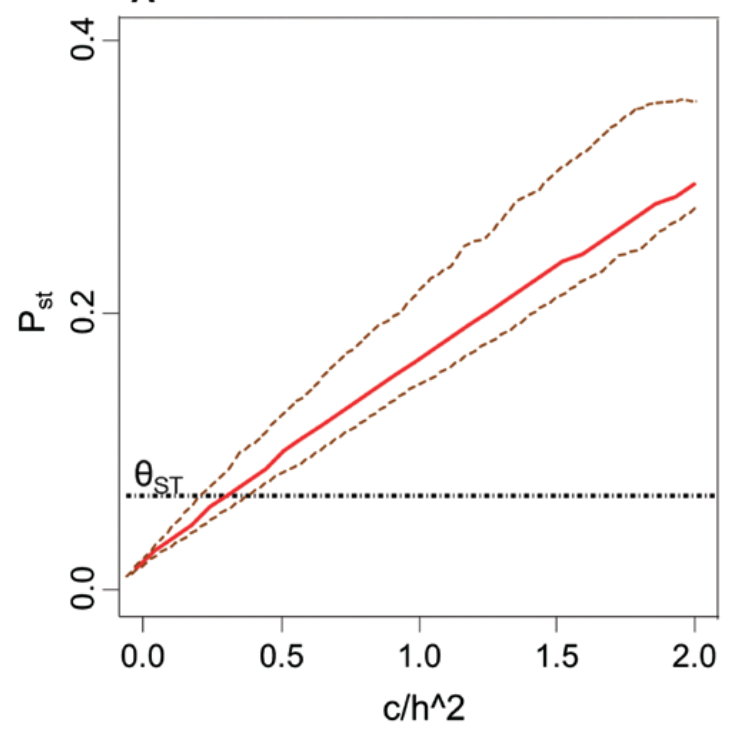

B

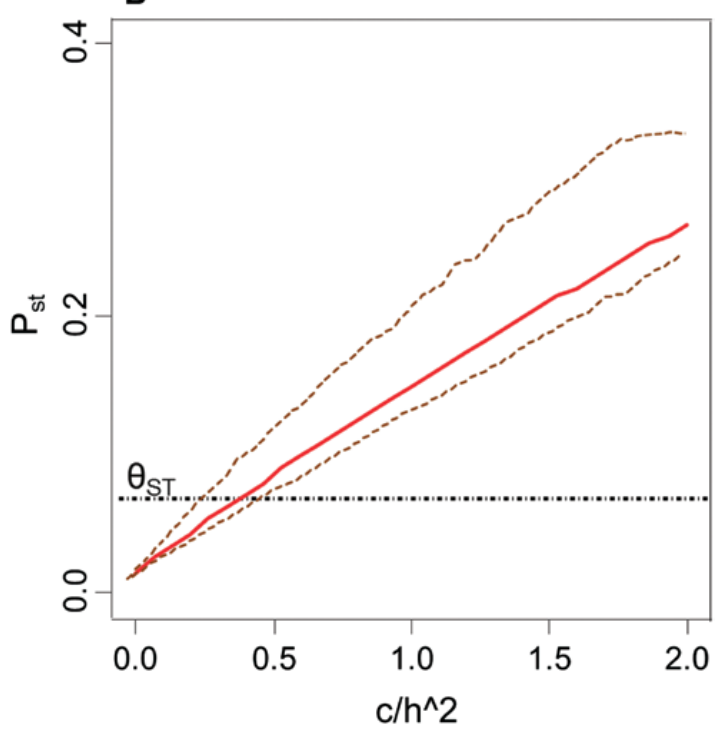

Figure 4. $P_{S T}$ simulation ( \pm c.i.) for continuous varying $\frac{c}{h^{2}}$ and upper $\theta_{S T}$ comparison. A, Vegetative traits and B, reproductive traits.

Table 2. Analysis of variance on AFLP (based on AMOVA) and on phenotypic vegetative and reproductive traits (based on ANOVA performed on first axis PCA scores). MSD: Mean squared deviation and percentage of variation explained by collection site, soil type within collection site and site $\times$ soil interaction. $* P<0.05, * * P<0.01, * * * P<0.001$; NS, non-significant.

d.f.

AFLP

Among sites

Among soils

Among soil*site

Within populations

Vegetative traits

Among sites

Among soils

Among soil $\times$ site

Within populations

Reproductive traits

Among sites

Among soils

Among soil $\times$ site

Within populations
MSD

85.370

52.063

56.310

26.927

29.534

19.676

14.531

4.138

26.671

0.775

16.122

6.028
Percentage of total variance

$2.33 * * *$

$0.62 * * *$

$5.00 * * *$

93.06

$12.85 * * *$

$1.92 *$

$6.76 * *$

65.25

$8.37 * * *$

$0.05 \mathrm{NS}$

$5.23 * *$

80.38 taken into account, a part of these significant correlations disappeared (Table 4B). However, correlations between phenotypic traits and mean July temperature and number of frost days remained significant (marginally significant for reproductive traits, Table 4B, Fig. S2). Additionally, the correlation between corrected vegetative traits and mean annual temperature was marginally significant.

\section{DISCUSSION}

\section{STRUCTURE OF GENETIC DIVERSITY REVEALED BY NEUTRAL MOLECULAR MARKERS}

In this study, we obtained new insights into the spatial distribution of genetic diversity in $B$. retusum, the key grass species of a vulnerable grassland habitat in the western Mediterranean. The number of polymorphic loci was higher than in other perennial Brachypodium 
Table 3. Multiple regression analysis (MRM). Standardized regression coefficients of multiple regression on distance matrices, with climatic distance, geographical distance and genetic distance in AFLP markers $\left(\theta_{S T}\right)$ as explanatory and pairwise $P_{S T}$ distances as response variables. $R^{2}$ : multiple correlation coefficient. MS marginally significant $P<0.1$, $* P<0.05, * * P<0.01,{ }^{*} * * P<0.001 ;$ NS, non-significant.

\begin{tabular}{lllll}
\hline Variables & \multicolumn{2}{c}{$P_{S T}$ vegetative traits } & & $P_{S T}$ reproductive traits \\
\cline { 2 - 4 } & Coefficient & $P$-value & & Coefficient \\
\hline Climate & 0.18 & $0.04 *$ & 0.07 & $0.05 *$ \\
Geographical distance & 0.10 & $0.20 \mathrm{NS}$ & 0.03 & $0.06 \mathrm{MS}$ \\
$\theta_{S T}$ & 1.65 & $0.04 *$ & 1.69 & $0.13 \mathrm{NS}$ \\
$\mathrm{pH}$ & 0.03 & $0.60 \mathrm{NS}$ & 0.01 & $0.70 \mathrm{NS}$ \\
$R^{2}$ & 0.57 & $0.02 *$ & 0.52 & $0.04 *$ \\
\hline
\end{tabular}

Table 4. Partial distance-based redundancy analyses (dbRDA) testing for effects of environmental factors on divergence in vegetative and reproductive traits $\left(P_{S T}\right)$. A, marginal test of individual sets of predictor variables and B, partial (conditional) test including geographical distance (latitude, longitude) and genetic distance as covariates. $F$-values, significance levels of ANOVA-like permutation tests and percentage of variation explained by each environmental factor. MS marginally significant $P<0.1, * P<0.05$, $* * P<0.01$, $* * * P<0.001$; NS, non-significant.

\begin{tabular}{|c|c|c|c|c|}
\hline & \multicolumn{2}{|c|}{$P_{S T}$ vegetative traits } & \multicolumn{2}{|c|}{$P_{S T}$ reproductive traits } \\
\hline & $F$-values & Explained variation (\%) & $F$-values & Explained variation (\%) \\
\hline \multicolumn{5}{|l|}{ A: Marginal tests } \\
\hline Precipitation & $6.606 *$ & 18.12 & $3.883 *$ & 15.48 \\
\hline Mean annual temperature & $4.007 *$ & 8.29 & $2.072 \mathrm{NS}$ & 8.27 \\
\hline Mean January temperature & $5.336 *$ & 13.84 & $3.651 *$ & 13.61 \\
\hline Mean July temperature & $5.048 *$ & 13.04 & $3.669 *$ & 14.20 \\
\hline Days $T<0$ & $6.181 *$ & 16.95 & $3.796 *$ & 15.15 \\
\hline $\mathrm{pH}$ & $4.001 *$ & 13.20 & $2.507 \mathrm{NS}$ & 9.94 \\
\hline \multicolumn{5}{|l|}{ B: Conditional tests } \\
\hline Precipitation & $0.803 \mathrm{NS}$ & 3.30 & $0.905 \mathrm{NS}$ & 7.21 \\
\hline Mean annual temperature & $3.000 \mathrm{NS}$ & 10.20 & $1.318 \mathrm{NS}$ & 11.50 \\
\hline Mean January temperature & $2.142 \mathrm{NS}$ & 8.21 & $1.120 \mathrm{NS}$ & 10.81 \\
\hline Mean July temperature & $5.362 *$ & 22.60 & $2.961 \mathrm{MS}$ & 26.20 \\
\hline Days $T<0$ & $6.345 *$ & 25.80 & 3.488 MS & 31.00 \\
\hline $\mathrm{pH}$ & $2.839 \mathrm{NS}$ & 11.31 & $2.124 \mathrm{NS}$ & 19.42 \\
\hline
\end{tabular}

spp. [B. pinnatum (L.) P.Beauv., B. sylvaticum (Huds.) P.Beauv.] and in the annual B. distachyon (L.) P.Beauv., but its genetic diversity was lower (Bąba et al., 2012; Mo et al., 2013; Zhang et al., 2012). Brachypodium retusum is a widespread, outcrossing, wind-pollinated species with high self-incompatibility (Catalán et al., 2015). These reproductive characteristics favour high levels of genetic variability (Ge et al., 1999; Nybom \& Bartish, 2000). However, longevity and in particular clonal growth may have reduced diversity compared with other perennial Brachypodium spp. (Young et al., 1996). Indeed, most populations showed linkage disequilibrium, associations between alleles at different loci (rbarD, Table 1), indicating a potential effect of asexual reproduction on genetic diversity (Kamvar, Tabima \& Grünwald, 2014).
Brachypodium spp. show different ploidies that may influence the above-mentioned genetic and phenotypic traits (Catalán et al., 2012). Allopolyploids, such as $B$. retusum, are often characterized by fixed heterozygosity and higher genetic diversity levels compared with their diploid progenitors (B. distachyon, B. sylvaticum) and inbreeding depression is usually lower (Soltis \& Soltis, 2000). Our study did not confirm the expectation of high genetic diversity in such a polyploid species, which may be due to cumulative effects of inbreeding, genetic drift and/or a narrow genetic basis at allopolyploid formation.

The cluster analysis of genetic differentiation (UPGMA, Fig. 1) revealed that Spanish and Italian populations are clearly separated from southern 
French populations except for one of the easternmost French populations (MO_R). Geographically, this population was closer to the Spanish populations than most of the other French populations. However, the French ROQ population, even closer to the Spanish border, clusters with the other French populations. At the regional southern French scale, analyses of AFLP data showed a low differentiation between populations $\left(\theta_{S T}\right.$ of $\left.7.2 \%\right)$ associated with strong admixture and weak geographical pattern (Structure, Figs 2, 3). Such a low genetic structuring at the regional scale is typical for outcrossing species with long-distance gene flow and was also found for the outcrossing $B$. pinnatum (Bąba et al., 2012).

\section{REGIONAL-SCALE GENETIC STRUCTURE: PHENOTYPIC AND GENOMIC DIFFERENTIATION}

In southern French populations, $P_{S T}$ was higher than $\theta_{S T}$ indicating divergent natural selection (Volis et al., 2005; Leinonen et al., 2013). Critical $\frac{c}{h^{2}}$ was low confirming that the difference between neutral molecular and phenotypic differentiation is significant and robust (Brommer, 2011). Although non-adaptive phenotypic differentiation (Ghalambor et al., 2007) may have contributed to higher $P_{S T}$, the most likely explanation of the difference from $\theta_{S T}$ is adaptation to local environments (Volis et al., 2005; Leinonen et al., 2013).

No isolation-by-distance was found in phenotypic traits, but a significant effect of $\theta_{S T}$ on vegetative phenotypic traits still showed an influence of neutral processes on phenotypic differentiation. Genetic drift and gene flow are also major drivers of population differentiation in phenotypic traits (e.g. Lande, 1976; Orsini et al., 2013). However, effects of environmental conditions on phenotypic differentiation measured in a common garden experiment remained significant after controlling geographical and genetic distance based on AFLP (Table 4). This finding supports that divergent directional selection led to adaptive differentiation. The major environmental factors associated with phenotypic differentiation and remaining significant after correction for neutral marker differentiation were summer temperature and number of frost days. Summer temperatures are closely related to drought stress strongly affecting plant fitness and survival in Mediterranean systems and in particular limiting seedling recruitment (Bochet et al., 2007; Thomas et al., 2010; Giovino et al., 2014; Vidaller et al., 2018). Southern French populations are relatively close to the northern range limit of $B$. retusum (San Miguel, 2008; Catalán et al., 2015). Thus, it is likely that frost is a strong selective force contributing to population differentiation (e.g. Kreyling et al., 2012a, b). Frost has been identified as a major driver of population differentiation in trees (Savolainen et al., 2004; Kreyling et al., 2012a) and in some herbaceous species (Agrawal, Conner \& Stinchcombe, 2004; Kreyling et al., 2012b).

Soil type within sampling sites explained a significant part of variation among populations in neutral markers and in vegetative phenotypic traits. However, explained variation was much smaller between soils within sites than between sites, suggesting that soil was not a major driver of genetic structure. The soil $\mathrm{pH}$ as the principal difference between the two tested soil types had no effect on phenotypic differentiation $\left(P_{S T}\right)$ when corrected for the influence of genetic drift or geographical distance. Small-scale adaptive differentiation to soil conditions has been shown for sites contaminated with heavy metals (Ernst, 1987), but environmental gradients were strong in the cited studies. If gradients are less strong, gene flow may prevent adaptive differentiation at smaller scales (Leimu \& Fischer, 2008; Hereford, 2009). Thus, adaptation to soil conditions often showing small-scale variation was not always detected or its magnitude was smaller than that of climate. Climate usually acts at larger scales and is thus less sensitive to homogenizing gene flow (Macel et al., 2007; Raabová et al., 2007).

Comparisons of $P_{S T}-\theta_{S T}$ share several limitations with comparisons of $Q_{S T}-F_{S T}$ such as difficulties in parameter estimations and a combination of low gene flow and high mutation rates in several genomic markers such as microsatellites leading to lower $F_{S T} / \theta_{S T}$ estimates (Edelaar, Burraco \& Gomez-Mestre, 2011; Whitlock \& Gilbert, 2012). However, in our study, phenotypic differentiation was clearly higher than neutral molecular variation that was significantly affected by gene flow. We thus believe that our results provide strong evidence for adaptive differentiation. In addition to $Q_{S T}$ studies, the $P_{S T}$ values are potentially more sensitive to environmental effects on phenotypic variance. As recommended by Brommer (2011), we measured phenotypic traits on common garden plants to limit this bias.

Even under standardized environmental conditions such as those provided by common garden settings, the observed phenotypic differentiation may comprise non-genetic variation due to environmental maternal effects. Maternal effects may persist several generations (transgenerational plasticity: Galloway \& Etterson, 2007). To limit such maternal effects on phenotypic differentiation, we only used late developmental traits that are less influenced by the maternal environment (Roach $\&$ Wulff, 1987; Donohue, 2009). However, non-resourcerelated transgenerational plasticity may persist for several generations (Galloway \& Etterson, 2007). We can thus not fully exclude an influence of environmental maternal effects on phenotypic differentiation. Sensitivity analyses of 
different simulated heritability values showed that effects of non-additive genetic variation are small in estimates of phenotypic differentiation relative to neutral molecular differentiation (Saether et al., 2007; Lehtonen et al., 2009). A meta-analysis of 62 empirical studies demonstrated that the $Q_{S T}-F_{S T}$ comparisons are relatively robust to effects of the maternal environment (Leinonen et al., 2008).

Finally, allopolyploids are characterized by a strong phenotypic plasticity that can be explained by different levels of homologous expression (Yoo, Szadkowski \& Wendel, 2013). This phenotypic plasticity caused by different patterns of gene expression should also act at local scale (Thompson et al., 1991; Castillo et al., 2018). However, we observed low phenotypic differentiation at local scales compared with regional scales supporting our conclusion that B. retusum population differentiation is driven by regional environmental gradients.

\section{CONCLUSIONS}

Brachypodium retusum populations in the western Mediterranean Basin showed high genetic diversity and weak to moderate differentiation between populations. Patterns of differentiation in neutral markers suggest a predominant influence of genetic drift. At the regional scale in southern France, both divergent selection and drift were detected by comparing phenotypic and neutral molecular differentiation. The major driver of adaptive differentiation was climate, in particular summer temperature and winter frost frequency. The two main soil types of the region contributed significantly to population differentiation but explained much less variation than climate and genetic drift at larger scales. Adaptive differentiation driven by environmental factors acting at regional scales is therefore a plausible pattern of phenotypic evolution in $B$. retusum. Accordingly, plant provenance targeting in ecological restoration needs to consider this spatial and environmental pattern of population differentiation. Local seed collected on the same soil type should be preferred, but proximity of source populations seems to be more important than corresponding soil type.

\section{FUNDING}

This work was supported by the Région PACA ( $\mathrm{PhD}$ grant) and the University of Avignon (Excellence program).

\section{ACKNOWLEDGEMENTS}

We thank Daniel Pavon, Elise Buisson, Hervé Ramone, Kevin Maurin and Cándido Gálvez Ramírez (Semillas
Silvestres) for collecting seeds. Vivien Carrere and Lara Amorsi helped in setting up the common garden experiment. We are grateful to Anne Blondeau Da Silva for advice in using $R$ Pstat package. The study benefited from the help of Anne Roig, equipment and services of the molecular biology facility (SCBM) at the IMBE and of genotyping facilities of the INRA (URFM Avignon).

\section{REFERENCES}

Agrawal AA, Conner JK, Stinchcombe JR. 2004. Evolution of plant resistance and tolerance to frost damage. Ecology Letters 7: 1199-1208.

Arrigo N, Tuszynski JW, Ehrich D, Gerdes T, Alvarez N. 2009. Evaluating the impact of scoring parameters on the structure of intra-specific genetic variation using RawGeno, an $\mathrm{R}$ package for automating AFLP scoring. BMC Bioinformatics 10: 33.

Bąba W, Kurowska M, Kompała-Bąba A, Wilczek A, Długosz J, Szarejko I. 2012. Genetic diversity of the expansive grass Brachypodium pinnatum in a changing landscape: effect of habitat age. Flora - Morphology, Distribution, Functional Ecology of Plants 207: 346-353.

Balao F, Valente LM, Vargas P, Herrera J, Talavera S. 2010. Radiative evolution of polyploid races of the Iberian carnation Dianthus broteri (Caryophyllaceae). The New Phytologist 187: 542-551.

Becker U, Dostal P, Jorritsma-Wienk LD, Matthies D. 2008. The spatial scale of adaptive population differentiation in a wide-spread, well-dispersed plant species. Oikos 117: 1865-1873.

Bertin A, Gouin N, Baumel A, Gianoli E, Serratosa J, Osorio R, Manel S. 2017. Genetic variation of loci potentially under selection confounds species-genetic diversity correlations in a fragmented habitat. Molecular Ecology 26: 431-443.

Bochet E, García-Fayos P, Alborch B, Tormo J. 2007. Soil water availability effects on seed germination account for species segregation in semiarid roadslopes. Plant and Soil 295: $179-191$.

Breed MF, Harrison PA, Bischoff A, Durruty P, Gellie NJC, Gonzales EK, Havens K, Karmann M, Kilkenny FF, Krauss SL, Lowe AJ, Marques P, Nevill PG, Vitt PL, Bucharova A. 2018. Priority actions to improve provenance decision-making. BioScience 68: 510-516.

Brommer JE. 2011. Whither $P_{S T}$ ? The approximation of $Q_{S T}$ by $P_{S T}$ in evolutionary and conservation biology. Journal of Evolutionary Biology 24: 1160-1168.

Bucharova A, Michalski S, Hermann J-M, Heveling K, Durka W, Hölzel N, Kollmann J, Bossdorf O. 2016. Genetic differentiation and regional adaptation among seed origins used for grassland restoration: lessons from a multispecies transplant experiment. Journal of Applied Ecology 54: 127-136.

Bullock JM, Pywell RF, Burke MJW, Walker KJ. 2001. Restoration of biodiversity enhances agricultural production. Ecology Letters 4: 185-189. 
Castillo JM, Gallego-Tévar B, Figueroa E, Grewell BJ, Vallet D, Rousseau H, Keller J, Lima O, Dréano S, Salmon A, Aïnouche M. 2018. Low genetic diversity contrasts with high phenotypic variability in heptaploid Spartina densiflora populations invading the Pacific coast of North America. Ecology and Evolution 8: 4992-5007.

Catalán P, López-Álvarez D, Díaz-Pérez A, Sancho R, López-Herránz ML. 2015. Phylogeny and evolution of the genus Brachypodium. In: Vogel JP, ed. Plant genetics and genomics: crops and models. Genetics and genomics of Brachypodium. Chamonix: Springer International Publishing, 9-38.

Catalán P, Müller J, Hasterok R, Jenkins G, Mur LA, Langdon T, Betekhtin A, Siwinska D, Pimentel M, López-Alvarez D. 2012. Evolution and taxonomic split of the model grass Brachypodium distachyon. Annals of Botany 109: 385-405.

Caturla RN, Raventós J, Guàrdia R, Vallejo VR. 2000. Early post-fire regeneration dynamics of Brachypodium retusum Pers. (Beauv.) in old fields of the Valencia region (eastern Spain). Acta Oecologica 21: 1-12.

Coiffait-Gombault C, Buisson E, Dutoit T. 2012. Are old Mediterranean grasslands resilient to human disturbances? Acta Oecologica 43: 86-94.

Da Silva SB, Da Silva A. 2018. Pstat: an R package to assess population differentiation in phenotypic traits. The $R$ Journal 10: 447-454.

Donohue K. 2009. Completing the cycle: maternal effects as the missing link in plant life histories. Philosophical Transactions of the Royal Society B: Biological Sciences 364: 1059-1074.

Durka W, Michalski SG, Berendzen KW, Bossdorf O, Bucharova A, Hermann J-M, Hölzel N, Kollmann J. 2017. Genetic differentiation within multiple common grassland plants supports seed transfer zones for ecological restoration. Journal of Applied Ecology 54: 116-126.

Edelaar P, Burraco P, Gomez-Mestre I. 2011. Comparisons between $Q_{(S T)}$ and $F_{(S T)}$-how wrong have we been? Molecular Ecology 20: 4830-4839.

Ernst WHO. 1987. Population differentiation in grassland vegetation. In: Van Andel J, Bakker JP, Snaydon RW, eds. Disturbance in grasslands: causes, effects and processes. Geobotany. Dordrecht, Netherlands: Springer, 213-228.

Evanno G, Regnaut S, Goudet J. 2005. Detecting the number of clusters of individuals using the software STRUCTURE: a simulation study. Molecular Ecology 14: 2611-2620.

Foll M, Gaggiotti O. 2008. A genome-scan method to identify selected loci appropriate for both dominant and codominant markers: a Bayesian perspective. Genetics 180: 977-993.

Freitas H, Mooney H. 1996. Effects of water stress and soil texture on the performance of two Bromus hordeaceus ecotypes from sandstone and serpentine soils. Acta Oecologica 17: 307-317.

Galloway LF, Etterson JR. 2007. Transgenerational plasticity is adaptive in the wild. Science (New York, N.Y.) 318: 1134-1136.

Ge S, Oliveira GC, Schaal BA, Gao LZ, Hong DY. 1999. RAPD variation within and between natural populations of the wild rice Oryza rufipogon from China and Brazil. Heredity 82 (Pt 6): 638-644.

Ghalambor CK, McKay JK, Carroll SP, Reznick DN. 2007. Adaptive versus non-adaptive phenotypic plasticity and the potential for contemporary adaptation in new environments. Functional Ecology 21: 394-407.

Giovino A, Scibetta S, Saia S, Guarino C. 2014. Genetic and morphologic diversity of European fan palm (Chamaerops humilis L.) populations from different environments from Sicily. Botanical Journal of the Linnean Society 176: 66-81.

Hardion L, Baumel A, Verlaque R, Vila B. 2014. Distinct evolutionary histories of lowland biota on Italian and Balkan peninsulas revealed by the phylogeography of Arundo plinii (Poaceae). Journal of Biogeography 41: 2150-2161

Hereford J. 2009. A quantitative survey of local adaptation and fitness trade-offs. The American Naturalist 173: 579-588.

Hereford J, Winn AA. 2008. Limits to local adaptation in six populations of the annual plant Diodia teres. The New Phytologist 178: 888-896.

Hufford KM, Mazer SJ. 2003. Plant ecotypes: genetic differentiation in the age of ecological restoration. Trends in Ecology \& Evolution 18: 147-155.

Hufford KM, Mazer SJ. 2012. Local adaptation and the effects of grazing on the performance of Nassella pulchra: implications for seed. sourcing in restoration. Restoration Ecology 20: 688-695.

Kamvar ZN, Tabima JF, Grünwald NJ. 2014. Poppr: an $\mathrm{R}$ package for genetic analysis of populations with clonal, partially clonal, and/or sexual reproduction. PeerJ 2: e281.

Kort HD, Vandepitte K, Honnay O. 2013. A meta-analysis of the effects of plant traits and geographical scale on the magnitude of adaptive differentiation as measured by the difference between $Q_{S T}$ and $F_{S T}$. Evolutionary Ecology 27: 1081-1097.

Kreyling J, Thiel D, Nagy L, Jentsch A, Huber G, Konnert M, Beierkuhnlein C. 2012a. Late frost sensitivity of juvenile Fagus sylvatica L. differs between southern Germany and Bulgaria and depends on preceding air temperature. European Journal of Forest Research 131: 717-725.

Kreyling J, Thiel D, Simmnacher K, Willner E, Jentsch A, Beierkuhnlein C. 2012b. Geographic origin and past climatic experience influence the response to late spring frost in four common grass species in central Europe. Ecography 35: 268-275.

Lande R. 1976. Natural selection and random genetic drift in phenotypic evolution. Evolution; International Journal of Organic Evolution 30: 314-334.

Legendre P, Anderson MJ. 1999. Distance-based redundancy analysis: testing multispecies responses in multifactorial ecological experiments. Ecological Monographs 69: 1-24.

Lehtonen PK, Laaksonen T, Artemyev AV, Belskii E, Both C, Bures S, Bushuev AV, Krams I, Moreno J, Mägi M, Nord A, Potti J, Ravussin PA, Sirkiä PM, Saetre GP, Primmer CR. 2009. Geographic patterns of genetic differentiation and plumage colour variation are different in the pied flycatcher (Ficedula hypoleuca). Molecular Ecology 18: 4463-4476.

Leimu R, Fischer M. 2008. A meta-analysis of local adaptation in plants. PLoS One 3: e4010. 
Leinonen T, McCairns RJ, O'Hara RB, Merilä J. 2013. $Q_{(S T)}-F_{(S T)}$ comparisons: evolutionary and ecological insights from genomic heterogeneity. Nature Reviews. Genetics 14: 179-190.

Leinonen T, O'Hara RB, Cano JM, Merilä J. 2008. Comparative studies of quantitative trait and neutral marker divergence: a meta-analysis: $Q_{S T}-F_{S T}$ meta-analysis. Journal of Evolutionary Biology 21: 1-17.

Lenormand T. 2002. Gene flow and the limits to natural selection. Trends in Ecology \& Evolution 17: 183-189.

Macel M, Lawson CS, Mortimer SR, Smilauerova M, Bischoff A, Crémieux L, Dolezal J, Edwards AR, Lanta V, Bezemer TM, Van der Putten WH, Igual JM, Rodriguez-Barrueco C, Müller-Schärer H, Steinger T. 2007. Climate vs. soil factors in local adaptation of two common plant species. Ecology 88: 424-433.

Manel S, Gugerli F, Thuiller W, Alvarez N, Legendre P, Holderegger R, Gielly L, Taberlet P; IntraBioDiv Consortium. 2012. Broad-scale adaptive genetic variation in alpine plants is driven by temperature and precipitation. Molecular Ecology 21: 3729-3738.

Meimberg H, Milan NF, Karatassiou M, Espeland EK, McKay JK, Rice KJ. 2010. Patterns of introduction and adaptation during the invasion of Aegilops triuncialis (Poaceae) into Californian serpentine soils. Molecular Ecology 19: 5308-5319.

Mo X, Gao J, Gao L. 2013. Characterization of microsatellite markers and their application to genetic diversity analysis of Brachypodium sylvaticum var. breviglume from Yunnan, China. American Journal of Plant Sciences 4: 1427-1434.

Nybom H, Bartish IV. 2000. Effects of life history traits and sampling strategies on genetic diversity estimates obtained with RAPD markers in plants. Perspectives in Plant Ecology, Evolution and Systematics 3: 93-114.

Orsini L, Vanoverbeke J, Swillen I, Mergeay J, De Meester L. 2013. Drivers of population genetic differentiation in the wild: isolation by dispersal limitation, isolation by adaptation and isolation by colonization. Molecular Ecology 22: 5983-5999.

Peakall R, Smouse PE. 2012. GenAlEx 6.5: genetic analysis in Excel. Population genetic software for teaching and researchan update. Bioinformatics (Oxford, England) 28: 2537-2539.

Pritchard JK, Wen X, Falush D. 2007. Documentation for Structure software: version 2.2. Available at: http.pritch.bsd. uchicago.edu/software.

Raabová J, Münzbergová Z, Fischer M. 2007. Ecological rather than geographic or genetic distance affects local adaptation of the rare perennial herb, Aster amellus. Biological Conservation 139: 348-357.

Raabová J, Münzbergová Z, Fischer M. 2011. The role of spatial scale and soil for local adaptation in Inula hirta. Basic and Applied Ecology 12: 152-160.

Roach D, Wulff R. 1987. Maternal effects in plants. Annual Review of Ecology and Systematics 18: 209-235.

Saether SA, Fiske P, Kålås JA, Kuresoo A, Luigujõe L, Piertney SB, Sahlman T, Höglund J. 2007. Inferring local adaptation from $Q_{S T}-F_{S T}$ comparisons: neutral genetic and quantitative trait variation in European populations of great snipe. Journal of Evolutionary Biology 20: 1563-1576.

San Miguel A. 2008. Management of Natura 2000 habitats. 6220* Pseudo-steppe with grasses and annuals (TheroBrachypodietea). Brussels: European Commission.

Savolainen O, Bokma F, García-Gil R, Komulainen P, Repo T. 2004. Genetic variation in cessation of growth and frost hardiness and consequences for adaptation of Pinus sylvestris to climatic changes. Forest Ecology and Management 197: 79-89.

Segarra-Moragues JG, Carrión Marco Y, Castellanos MC, Molina MJ, García-Fayos P. 2016. Ecological and historical determinants of population genetic structure and diversity in the Mediterranean shrub Rosmarinus officinalis (Lamiaceae). Botanical Journal of the Linnean Society 180: $50-63$.

Sexton JP, Hangartner SB, Hoffmann AA. 2014. Genetic isolation by environment or distance: which pattern of gene flow is most common? Evolution; International Journal of Organic Evolution 68: 1-15.

Sherrard ME, Maherali H. 2012. Local adaptation across a fertility gradient is influenced by soil biota in the invasive grass, Bromus inermis. Evolutionary Ecology 26: $529-544$.

Soltis PS, Soltis DE. 2000. The role of genetic and genomic attributes in the success of polyploids. Proceedings of the National Academy of Sciences of the United States of America 97: 7051-7057.

Thomas PB, Morris EC, Auld TD, Haigh AM. 2010. The interaction of temperature, water availability and fire cues regulates seed germination in a fire-prone landscape. Oecologia 162: 293-302.

Thompson JD, McNeilly T, Gray AJ. 1991. Population variation in Spartina anglica CE Hubbard: III. Response to substrate variation in a glasshouse experiment. New Phytologist 117: 141-152

Van der Putten WH, Anderson JM, Bardgett RD, BehanPelletier VM, Bignell D, Brown GG, Brown VK, Brussaard L, Hunt HW, Ineson P, Jones TH. 2004. The sustainable delivery of goods and services provided by soil biota. In: Wall DH, ed. Sustaining biodiversity and ecosystem services in soils and sediments. Washington: Island Press, $15-44$.

Vander Mijnsbrugge K, Bischoff A, Smith B. 2010. A question of origin: where and how to collect seed for ecological restoration. Basic and Applied Ecology 11: 300-311.

Vidaller C, Dutoit T, Ibrahim Y, Hanslin HM, Bischoff A. 2018. Adaptive differentiation among populations of the Mediterranean dry grassland species Brachypodium retusum: the role of soil conditions, grazing, and humidity. American Journal of Botany 105: 1-10.

Vilas A, Pérez-Figueroa A, Caballero A. 2012. A simulation study on the performance of differentiation-based methods to detect selected loci using linked neutral markers. Journal of Evolutionary Biology 25: 1364-1376.

Volis S, Yakubov B, Shulgina I, Ward D, Mendlinger S. 2005. Distinguishing adaptive from nonadaptive genetic 
differentiation: comparison of $Q_{S T}$ and $F_{S T}$ at two spatial scales. Heredity 95: 466-475.

Vos P, Hogers R, Bleeker M, Reijans M, van de Lee T, Hornes M, Frijters A, Pot J, Peleman J, Kuiper M. 1995. AFLP: a new technique for DNA fingerprinting. Nucleic Acids Research 23: 4407-4414.

Wardle DA. 2002. Communities and ecosystems: linking the aboveground and belowground components. Princeton: Princeton University Press.

Whitlock MC, Gilbert KJ. 2012. Q(ST) in a hierarchically structured population. Molecular Ecology Resources 12: 481-483.

Wolny E, Hasterok R. 2009. Comparative cytogenetic analysis of the genomes of the model grass Brachypodium distachyon and its close relatives. Annals of Botany 104: 873-881.
Wolny E, Lesniewska K, Hasterok R, Langdon T. 2011. Compact genomes and complex evolution in the genus Brachypodium. Chromosoma 120: 199-212.

Yoo MJ, Szadkowski E, Wendel JF. 2013. Homoeolog expression bias and expression level dominance in allopolyploid cotton. Heredity 110: 171-180.

Young A, Boyle T, Brown T. 1996. The population genetic consequences of habitat fragmentation for plants. Trends in Ecology \& Evolution 11: 413-418.

Zhang L, Jeon YJ, Kang SY, Lee GJ. 2012. Genetic diversity of natural and artificial populations of model grass Brachypodium species evaluated by AFLP markers. Horticulture, Environment, and Biotechnology 53: $143-150$.

\section{SUPPORTING INFORMATION}

Additional Supporting Information may be found in the online version of this article at the publisher's web-site:

Table S1. Soil characteristics, annual precipitation, mean annual air temperature (including January and July mean in brackets), and the number of frost days $(T<0)$ at collection sites. Sites are ranked from east to west. Climate data are based on daily averages from the nearest meteorological stations (1980-2010). Soil: $\mathrm{C}=$ calcareous soil, $\mathrm{R}=$ red Mediterranean soil, $*$ Soil on granite bedrock, not red Mediterranean soil but chemical properties closer to $\mathrm{F}$ than to $\mathrm{C}$.

Detailed method description 1. DNA extraction

Detailed method description 2. Critical formula

Table S2. Pairwise $\theta_{S T}$ among populations. $* P<0.05$, ** $P<0.01$, *** $P<0.001$; NS, non-significant.

Figure S1. Delta $K$, calculated according to Evanno et al. (2005) is plotted against the number of modelled gene pools $(K)$.

Table S3. Pairwise $P_{S T}$ between southern French populations for A, vegetative and B, reproductive traits. All pairwise comparisons were significant $(P<0.001)$.

Figure S2. Distance-based redundancy analysis (dbRDA) showing the influence of environmental variables on pairwise vegetative traits $P_{S T}$ among populations. The vectors illustrate correlations between the original environmental variables and the dbRDA-axes. 